\title{
Broiler Performance From Cull Eggs 1
}

\author{
Gary D. Butcher, DVM, Ph.D and Amir H. Nilipour, Ph.D²
}

In a commercial broiler integration, the objective is to provide the best quality hatching eggs that produce the greatest number of quality chicks per hen housed. A properly managed hen can produce more than 180 eggs, which potentially can result in approximately 600 pounds of broiler meat. However, there exists great variation in the amount of meat produced per hen among integrations. Much of this difference can be traced back to how the eggs were managed during collection, storage, and incubation. The production goals of an integration can be achieved when basic concepts of optimum fertile egg selection and grading, plus common sense management, are considered.

\section{What Is an Optimum Fertile Egg?}

In the fertile egg industry, optimum fertile eggs are described in general terms as those with high percent hatch rates that produce high quality, good sized chicks. However, to be of practical value, this definition needs to be expanded to include the production cost per chick and pound of meat, in relation to market demand for poultry meat and fertile eggs. Actually, the profit and net income can be increased when the largest number of eggs can be incubated per hen housed. Increases can be achieved, in some cases, even with a lower average chick weight and percent hatchability. Obtaining high percent hatches with heavy chicks might look good on paper, but it may adversely affect cost of production when egg selection is too stringent, especially when fertile eggs are in short supply.

\section{What Percent of Fertile Eggs Are Culls?}

Depending on a company's situation, there can be considerable variation in egg culling. For example, if there is a strong demand for fertile eggs, as was experienced during the worldwide Myeloid Leikosis problem in heavy breeders, the focus must be on hatching the maximum number of eggs. At a commercial poultry integration, evaluation of results from more than 85 million eggs collected showed that under normal field conditions, the percent of cull fertile eggs should not exceed $4.0 \%$ during a 40 -week production cycle. Table 1 shows the percent of the various categories for cull eggs during the four year period of the study.

These data are for normal conditions. However, if the market demands more fertile eggs and level of management at the breeder and broiler farms is excellent, less restrictive egg selection could be practiced. The $4 \%$ total cull eggs can be reduced to

1. This document is VM125, one of a series of the Animal Science Department, Florida Cooperative Extension Service, Institute of Food and Agricultural Sciences, University of Florida. Original publication date April 29, 2002. Visit the EDIS Web Site at http://edis.ifas.ufl.edu.

2. Gary D. Butcher, extension veterinarian, University of Florida College of Veterinary Medicine, Gainesville, FL

Amir H. Nilipour, PhD, Director of Investigation and Quality Assurance, Grupo Melo, S.A., Panama, Republic of Panama

The Institute of Food and Agricultural Sciences is an equal opportunity/affirmative action employer authorized to provide research, educational information and other services only to individuals and institutions that function without regard to race, color, sex, age, handicap, or national origin. For information on obtaining other extension publications, contact your county Cooperative Extension Service office. Florida Cooperative Extension Service/Institute of Food and Agricultural Sciences/University of Florida/Christine Taylor Waddill, Dean. 
2.5 to $3.0 \%$. This can be achieved by decreasing the number of cracked eggs, by saving the mildly deformed and porous eggs, and by reducing minimum egg weights for incubation.

Table 1. Categorizing cull eggs

\begin{tabular}{|c|c|}
\hline Category of cull egg & $\%$ \\
\hline Cracks/broken & 1.70 \\
\hline Double Yolk & 0.70 \\
\hline Pee Wee & 0.70 \\
\hline Dirty & 0.40 \\
\hline Deformed & 0.25 \\
\hline Porous & 0.25 \\
\hline Total & $\mathbf{4 . 0 0}$ \\
\hline
\end{tabular}

\section{Hatchability of Cull Eggs}

These studies have demostrated that many fertile eggs classified as culls can produce quality broilers, even though they have a reduced percent hatch. Use of these eggs is an efficient and practical way to increase the number of eggs and chicks produced per hen housed. Table 2 shows the results of more than 13,000 under-grade broiler fertile eggs that were incubated at the Poultry Integration Grupo Melo S.A. in Panama. Clearly, many fertile eggs that would have been discarded have the potential to hatch.

Table 2. Hatchability of undergrade eggs.

\begin{tabular}{|c|c|}
\hline Egg type & \% hatch \\
\hline Small & 60.76 \\
\hline Deformed & 52.32 \\
\hline Large & 45.86 \\
\hline Porous & 31.61 \\
\hline
\end{tabular}

As demonstrated in Table 2, with good husbandry, one to $2 \%$ more fertile eggs can be incubated when eggs are needed. Thus, $97-98 \%$ of the eggs laid may be used. Incubating eggs normally classified as culls would reduce the percent hatchability to some degree, but calculations of the costs to produce fertile eggs must be considered, especially when fertile eggs are in short supply. In addition, these eggs might have had even a higher percent hatchability if stored only 1-3 days. In the trials described in this paper, eggs were stored between 3-7 days to accumulate sufficient eggs for the experiment.

\section{Broiler Performance from Under-Grade Eggs}

Chicks hatched from eggs classified as deformed, porous or small are the same as those from regular eggs, except that chicks from smaller eggs are smaller. In two separate studies, chicks hatched from fertile cull eggs were raised in an experimental farm to 49 days of age. The objective was to determine the final broiler performance parameters, even though the percent hatch was lower. Tables 3 through 6 illustrate that resulting broiler performance was competitive with eggs classified as normal controls.

In trial 1 (Tables $3 \& 4$ ), it was interesting that chicks hatched from deformed and porous eggs had comparable body weights to the control group at 49 days of age.

In trial 2 (Tables $5 \& 6$ ), the same or better body weights were obtained for the broilers hatched from deformed eggs, followed by porous and small eggs. In both trials the cost to produce a pound of broiler meat was higher when cull fertile eggs were used. Increased production costs were less in males as compared to females for all 3 cull egg categories. However, these cost differences can be offset when there are higher meat prices such as when fertile eggs are in short supply.

\section{Chick Size Varies}

During the 40 -week broiler breeder production cycle, egg size normally varies from 45 to 72 grams, primarily depending on breeder age. Egg size has a direct impact on chick weight. Table 7 provides average chick body weights obtained in relation to breeder ages. More than 1/4 of the chicks produced during the peak of egg production, from breeders at 25-35 weeks of age, were less than 40 grams. Size variation can not be ignored. These chicks need extra attention to be as efficient and productive as the heavier chicks. 
Table 3. Female Broiler Performance--Trial 1

\begin{tabular}{|c|c|c|c|c|}
\hline Parameter & Control & Small & Deformed & Porous \\
\hline BW (gr) & 2182 & 2052 & 2256 & 2160 \\
\hline $\mathrm{Gr} /$ day & 44.60 & 41.88 & 46.08 & 44.08 \\
\hline Conversion & 1.905 & 1.999 & 2.038 & 1.93 \\
\hline $\begin{array}{c}\% \\
\text { Mortality }\end{array}$ & 3.64 & 0.00 & 2.63 & 0.00 \\
\hline Index & 225 & 209 & 220 & 228 \\
\hline $\begin{array}{c}\text { Cost/lb vs } \\
\text { Control } \\
\text { (cents) }\end{array}$ & 0.00 & 1.44 & 1.28 & 1.1 \\
\hline
\end{tabular}

Table 4. Male Broiler Performance--Trial 1

\begin{tabular}{|c|c|c|c|c|}
\hline Parameter & Control & Small & Deformed & Porous \\
\hline BW (gr) & 2526 & 2423 & 2689 & 2642 \\
\hline Gr./day & 51.55 & 49.45 & 54.87 & 53.92 \\
\hline Conversion & 1.919 & 2.01 & 1.966 & 1.871 \\
\hline $\begin{array}{c}\% \\
\text { Mortality }\end{array}$ & 3.64 & 3.77 & 7.14 & 10.00 \\
\hline Index & 259 & 237 & 259 & 259 \\
\hline $\begin{array}{c}\text { Cost/lb vs } \\
\text { control } \\
\text { (cents) }\end{array}$ & 0.00 & 1.46 & 0.43 & 0.86 \\
\hline
\end{tabular}

Table 5. Female Broiler Performance--Trial 2

\begin{tabular}{|c|c|c|c|c|}
\hline Parameter & Control & Small & Deformed & Porous \\
\hline BW (gr) & 2129 & 2026 & 2146 & 2127 \\
\hline Gr./day & 43.45 & 41.35 & 43.79 & 43.42 \\
\hline Conversion & 1.853 & 2.086 & 1.912 & 1.981 \\
\hline $\begin{array}{c}\% \\
\text { Mortality }\end{array}$ & 0.00 & 0.00 & 1.82 & 0.00 \\
\hline Index & 234 & 198 & 225 & 219 \\
\hline $\begin{array}{c}\text { Cost/lb vs } \\
\text { control } \\
\text { (cents) }\end{array}$ & 0.00 & 3.08 & 0.78 & 1.46 \\
\hline
\end{tabular}

Table 6. Male Broiler Performance--Trial 2

\begin{tabular}{|c|c|c|c|c|}
\hline Parameter & Control & Small & Deformed & Porous \\
\hline BW (gr) & 2532 & 2472 & 2509 & 2376 \\
\hline Gr./day & 51.67 & 50.45 & 51.21 & 48.49 \\
\hline Conversion & 1.854 & 1.843 & 1.855 & 1.857 \\
\hline $\begin{array}{c}\% \\
\text { Mortality }\end{array}$ & 3.64 & 3.64 & 5.45 & 5.00 \\
\hline \begin{tabular}{c} 
Index \\
\hline $\begin{array}{c}\text { Cost/lb vs } \\
\text { control } \\
\text { (cents) }\end{array}$
\end{tabular} & 0.00 & 0.12 & 0.36 & 0.84 \\
\hline
\end{tabular}


Table 7. Breeder age vs chick weight

\begin{tabular}{|c|c|c|c|c|}
\hline Parameter & Control & Small & Deformed & Porous \\
\hline BW (gr) & 2532 & 2472 & 2509 & 2376 \\
\hline Gr./day & 51.67 & 50.45 & 51.21 & 48.49 \\
\hline Conversion & 1.854 & 1.843 & 1.855 & 1.857 \\
\hline $\begin{array}{c}\text { \% } \\
\text { Mortality }\end{array}$ & 3.64 & 3.64 & 5.45 & 5.00 \\
\hline Index & 269 & 264 & 261 & 248 \\
\hline $\begin{array}{c}\text { Cost/lb vs } \\
\text { control } \\
\text { (cents) }\end{array}$ & 0.00 & 0.12 & 0.36 & 0.84 \\
\hline
\end{tabular}

\section{Extra Care for Small Chicks}

It must be emphasized that chicks from small eggs (less than 50 grams) have lower body weights (30-35 grams) and thus need extra attention when being transported to the farm and brooded. Small eggs should be collected and incubated separately. Following hatch, do not sex and mix with other regular size chicks. The small chicks should be sent to your best broiler farms, where the farm manager knows how to take care of these fragile, delicate animals and will provide special attention. These chicks need a couple extra days of brooding and additional vitamin supplementation. They should be marketed a couple of days later to reach the required body weight.

\section{Proper Training}

Many so-called "unfit fertile eggs" can be used, especially at times when a high demand for broiler fertile eggs and meat exists. When there is a fertile egg shortage, each cull egg merits reevaluation before it is declared unfit. The individuals responsible for classifying fertile eggs must be properly trained. They must know the standards and requirements for each egg category before pronouncing an egg unfit and culling. If increases in the number of cracked eggs, contaminated shells, and other flaws are seen, it must be recorded and reported to the respective farm manager to permit investigation and resolution of the problem. In many hatcheries visited, it has been observed that when the eggs arrive at the hatchery, the egg grader eliminates additional eggs, adding to the total of eggs

eliminated. The egg graders at the breeder farms and hatchery must be in constant communication with the hatchery manager, and know what is going on in the fertile egg market. Eggs unnecessarily eliminated increase production costs and reduce the company's profit margin. 